\title{
An Assessment Coffee Marketing Activities and Performance of Bonga Town Peasant Union
}

\author{
Tegegne Alemayehu \\ Lecturer at Woliata Sodo University, P.O.Box 138 Sodo, Ethiopia
}

\begin{abstract}
Ethiopia is the oldest coffee exporter in the world, even though In rural areas, householders are often geographically dispersed; roads and communications are poor, and the volume of business is insufficient to encourage private service provision. The purpose of this study is to assess the overall coffee marketing activities and performance of Bonga town peasant union. In this study, the type of research is descriptive. The rational for selecting this type of research is that the purpose of the study is describing the existing phenomenon of the coffee marketing activities and performance of Bonga town peasant union. This study employees both probability and non-probability sampling techniques. From non-probability convenience sampling technique was selected. Then, simple random sampling technique was used to select the representative sample from the population. The sampling frame for farmers was the registration list of the farmers around the town that consists of 443 at time of field survey. The combination of qualitative and quantitative data were employed. The data obtained from different sources is analyzed by using frequency tables and percentages. The main service found between farmers and the union is the marketing. The permanent customers for Coffee marketing union were member farmers, other farmers \& local traders. From the supply side the farmers \& other traders and the permanent buyer is the Union. The purchasing activity was done in most of the time by themselves and their family followed by using agents. The marketing service of the union is not that much fast and transparent and these results in poor performance of the union. Members in the study area, right after nominating the cooperatives managing body; were inclined to run away from their cooperatives and they were not controlling the physical and financial performances of their cooperatives. This situation opens the door for mismanagement of resources and lead to corruption. There were 33 private traders 13 cooperatives and four main marketing channels in which coffee was passing from producers to consumers. The first channel was passing coffee from producers via coffee marketing primary cooperatives to export through secondary cooperative (unions). In the second channel producers sold dried coffee to collectors who were selling to coffee marketing cooperatives to be exported directly through the Union. The third and the fourth channels participates rather larger number of marketing agents and in this way producers were selling their coffee either to collectors of dried cherry or wholesalers and collectors to wholesalers to export via exporter through auction market respectively. More active participation and coordination of members, directors, and managerial staff and government bodies are required to make the cooperatives become more competent and efficient, Giving greater emphasizes for member satisfaction the members, the management bodies and the staff members of the cooperatives need to be given a capacity building training in business planning and development and marketing management, Creating of conducive environment though formulation of sound cooperative policy that creates competitive cooperatives in satisfying their members. Keywords: Coffee, marketing, cooperatives (unions), Farmers
\end{abstract}

DOI: $10.7176 / \mathrm{JMCR} / 53-03$

\section{Background}

Ethiopia is the oldest coffee exporter in the world, though external invasions and internal conflicts have at times had a negative impact on the country's coffee export history. Coffee export in Harar goes back to earlier than 1810. In 1838, Rupell recorded the export of 100 quintals of Enarea-coffee (now Liumu-Seka, Jimma) via Massawa. In the 19th century, two coffee types, "specialty coffee", was exported as first and second grade Harari coffee and Abyssinia coffee to London, Marseilles, and New York.

In rural areas, householders are often geographically dispersed; roads and communications are poor, and the volume of business is insufficient to encourage private service provision (Mulat and Tadele, 2001).

Viaene (1977) cited in Barker (1989) identifies three new trends in the marketing of agricultural products by farmers; these are: (1) direct marketing to the consumer, bypassing the middlemen and reducing cost, (2) contract production, which benefits both producers and buyers; the farmer receives guarantees on finance and prices, thus reducing risks, and the buyer is assured of quality, quantity, and time of delivery and (3) Marketing through cooperatives, by farmers tending to improve their bargaining power.

Traditional Ethiopian coffee cultivation practices are still dominant among keffa farmers. Coffee trees are managed by hand and fertilized with organic matter .pests are controlled in biological, natural method. By this time the union has 12 organic certified coffee cooperatives producing 6,946 tons of washed and 13,892 sundry coffees annually available for the European, Japanese and American markets and five are registered for fair trade coffee sales (YCFCU, 2006). 


\subsection{Statement of the Problem}

Based on the principles of cooperatives, coffee farmers' marketing cooperatives are expected to genuinely perform their marketing activities and provide adequate services to their members. From time to time, it is essential to check whether they are on the right track or not. It will then contribute to the understanding of factors hindering improvement and modernization of the coffee farmers' marketing cooperatives.

To accomplish such an important task, empirical investigations have paramount importance in areas of coffee marketing cooperatives performance and level of members' satisfaction. This study, therefore, aims at assessing the performance of primary coffee marketing cooperatives, identifying their problems and opportunities as well as evaluate the level of members' satisfaction. Performance evaluation must combine various types of analysis that would provide the basis to analyze the functioning of the system, explain efficiencies, and assess the potential for and means of improving economic efficiency or other objectives. For achieving economic efficiency, a cooperative must plan, organize, motivate and control its operation (Knapp, 2000). As any other enterprises do, cooperatives need to also periodically control and evaluate their marketing activities. There are basically four types marketing controls, namely annual plan control, profitability control, efficiency control, and strategic control. However, in spite of a serious need to monitor and control marketing activities, many companies including cooperatives have inadequate control procedures (Kotler, 2003). There is no in-depth empirical study in Ethiopia supported with scientific research that shows the performance of primary coffee farmers marketing cooperative societies and/or their unions and the degree of satisfaction that members get from their cooperative societies. This research will, therefore, attempt to empirically investigate the above issues and bridge information gaps.

\subsection{Objectives of the study}

\subsubsection{General Objective}

The purpose of this study is to assess the overall coffee marketing activities and performance of Bonga town peasant union.

$>$ To assess the performance of coffee farmers' marketing union in Bonga town peasant union.

$>$ To study the extent of buying and selling strategy of the union

$>$ To identify key coffee marketing channels in Bonga town peasant union.

$>$ To identify major constraints and suggest suitable strategies for improvement.

\subsection{Research Questions}

Attempt will be made in this study to find answers for the following key questions.

1) What are the different marketing services provided by primary coffee marketing union and their union to their members?

2) What has been the performance of primary coffee farmers' marketing union?

3) What are the challenges and opportunities of their performance?

4) What are the key coffee marketing channels in Bonga town peasant union?

\subsection{Research Design and Methodology \\ 1.4.1. Research Design}

A research design is a conceptual structure that shows how all the major parts of the research project come together. According to Kothari (2004) it constitutes the blueprint for the collection, measurement and analysis of data. In this study, the type of research is descriptive. The rational for selecting this type of research is that the purpose of the study is describing the existing phenomenon of the coffee marketing activities and performance of Bonga town peasant union.

\subsection{2 .Sample Frame and \& Sampling Technique \\ Sampling Frame}

The sampling frame for farmers was the registration list of the farmers around the town that consists of $\mathbf{4 4 3}$ at time of field survey.

\section{Sample design and Technique}

In this research probability and non-probability sampling techniques were used. From non-probability convenience sampling technique was selected. Then, simple random sampling technique was used to select the representative sample from the population.

The Sample Size

The sample size was determined by the following formula

$$
n=\frac{N}{1+N(e)^{2}}
$$


$\mathrm{E}=$ is precision

$\mathrm{N}=$ is total population

$\mathrm{n}=$ is the desired sample size

Illustration

The total population $(\mathrm{N})$ of this study is $=443$

$\mathrm{n}=\mathrm{N} / 1+\mathrm{N}(\mathrm{e})^{2}$

As the above formula;

$\mathrm{n}=443 / 1+443(\mathrm{e})^{2}=443 / 3274.35185=0.135=13.5 \%$

$443 * 13.5=59.805 \approx \mathbf{6 0}$

Furthermore;

$95 \%$ is the confidence level

$\pm 5 \%$ or 0.05 is precision.

\subsubsection{Data Types and Data Sources}

Data Type:-the data that was employed for this research is the combination of qualitative and quantitative data. The quantitative method was used in collection \& analysis of data and for sampling techniques as required. Qualitative method was employed for data collection, interpretation, instrument development, \& conclusion and reporting.

Reasons for which the researcher needs to use the above methods in combination include are to make the study strong.

\section{Data Sources}

The study uses both primary and secondary data sources. Primary data is collected through a questionnaire distributed to the households in the kebeles. A sample of 60 households is taken by simple random sampling techniques. The secondary data is obtained from related literatures and annual reports of Bonga town peasant union.

\subsubsection{Data Analysis}

The data obtained from different sources is analyzed by using frequency tables and percentages.

\section{LITERATURE REVIEW}

\subsubsection{Market}

Market may be defined as "a particular group of people, an institution, a mechanism for facilitating exchange, (Solomon, 2002). The market concept has also been linked to the degree of communication among buyers and sellers and the degree of substitutability among gods. The concept of perfect market, for example, is an abstraction used by economists as a benchmark for evaluating the performance of market situations that deviate from its specifications (John and Sathan, 1988; cited in Solomon, 2002).

\subsubsection{Marketing}

The definitions of marketing can be grouped into two major categories: classical (narrow) definitions and modern (broad) definitions. In classical terms, marketing is defined as "the performance of business activities that direct the flow of goods and services from producer to consumer or user or the process in a society by which the demand structure for economic goods and services is anticipated (enlarged) and satisfied through the conception, promotion, and physical distribution of such goods and services". These classical definitions of marketing are oriented toward the physical movement of economic goods and services.

The breadth of marketing was officially recognized by the American Marketing Association (AMA) in 1985 when it replaced the classical definition it had approved in 1960 with the following: "Marketing is the process of planning and executing the conception, pricing, promotion, and distribution of ideas, goods, and services to create exchanges that satisfy individual and organizational objectives" (Joel R. Evans and Barry Berman, 1990).

There is no universally accepted definition of marketing, indicating the variety of options, which exist concerning the subject (Barker, 1989). Terpstra (1972) cited in Barker (1989) offers a very broad definition of marketing as "the collection of activities under taken by the firm to relate profitability to market".

Marketing is a societal process by which individuals and groups obtain what they need and want through creating, offering, and freely exchanging products and services and value with others (Kotler, 2003). Rodger (1971) cited in Barker (1989) offers a definition of marketing which is applicable to most agricultural systems: "marketing is the primary management function, which organizes and directs the aggregate business activities involved in converting consumer purchasing into effective demand for a specific product or service and in moving the specific product or service to the final customer or user so as to achieve company-set profit or other objectives" (Rodeger, 1971). The American Marketing Association (AMA) offers the following definitions: Marketing is the process of planning production, pricing, promotion, and distribution of ideas, goods, and services to create exchanges that satisfy individual and organizational goals (AMA (1995), cited in Kolter, 2003). 


\subsubsection{Evolution of modern marketing}

The modern marketing concept has evolved over a period of more than a century. The role and significance of marketing is primarily a function of the stages of economic development in a country. In a primitive society based on agriculture and handcrafts, exchange is very limited and marketing is more or less non-existent. In early stages of industrialization also, marketing does not pose a serious problem because of the excess of demand over supply. The main function of marketing in this stage is the movement of goods from the points of production to the points of consumption. In the third stage when production takes place on a mass scale, production exceeds demand and mass production needs mass distribution, marketing starts assuming an important role in the enterprise. In this stage, main focus of marketing is on selling and distribution. It is in an affluent economy where customer is highly sophisticated and his wants take a specific shape, marketing-orientation takes place (R.D Agarwal, 2004).

According to Agarwal (2004) the evolution of Modern Marketing stages is summarized as follows:

* Production - orientation: In a pre-industrial society as well as industrializing society, demand of most goods exceeds supply. Firms are mostly production-oriented, and the main function of marketing is the movement of goods from the production to the points of consumption.

* Sales-orientation: the excess of production over demand characterized the great depression of the thirties.

* Marketing-orientation: more and more companies are now putting increasingly greater emphasis on marketing. It is characterized by the integration of all marketing activities in the marketing division, and close coordination between marketing and other functions, particularly manufacturing, industrial engineering and credit management.

* Marketing Company Stage: At this stage, companies plan from market backward to the factory. Manufacturing and all other activities are guided by the market place.

* Social Responsibility- Future Orientation: Business enterprises will in future be more concerned with social responsibility in performing their marketing activities, in response to growing consumerism and threat of government intervention (Agarwal, 2004).

* Marketing can be studied from distinct standpoints. The two simplest, and probably most important, aspects identified are, on the one hand, marketing policy, which is concerned with macro-aggregate issues such as market structure, the nature and level of competition, the forms of, and reasons for, government intervention, and so on, and on the other hand, marketing management, which is related largely to issues confronting individual businesses (Barker, 1989).

\subsubsection{Agricultural marketing}

Agricultural marketing is the performance of all business activities involved in the flow of goods and services from the point of initial agricultural production until they are in the hands of the ultimate consumer (Kohls and Uhi, 1985).

The way in which farmers view their businesses depends very much on their personal aspirations and opinions. Two extreme positions, which can be identified, are those of 'production-oriented' and the 'marketingoriented' farmer. The production-oriented farmer regards the major part of his business as being concerned with the goods, which he wishes to produce. In contrast, the marketing-oriented farmer will endeavor to produce goods which can profitably be sold, giving due consideration to the likelihood of profit before production is under taken. It has been stated previously that production orientation is likely to be most successful in conditions where a seller's market exists and the control problem to be faced by farmers is to find ways of increasing output. Unfortunately, in agriculture this situation very rarely arises, apart from quirks arising for climatic reasons. The marketing orientation concept can be applied to agriculture to a large extent; to date however, there has been only a limited amount of work undertaken to define the orientations of farmers. (Mitchell (1975), cited in Barker, 1989) studied the extent to which, and the manner in which, farmers are influence in their livestock marketing decisions by publicly available sources of market information. He reached two general conclusions about the marketing behavior of farmers.

For the most part, farmers' actions with regard to marketing are he result of long-term policy decisions and as such will not be subject to review each time the farmer has occasion to sell. When marketing decisions are of a short-term nature, they will be influenced by many things, which do not come with in the preview of conventional market intelligence. Typical factors quoted as affecting sales decisions were prices, price expectation, and selling policy. (Bateman (1972), cited in Barker, 1989) gives a good illustration of he advantages accruing to farmers who utilize marketing Orirented management: 'Farmers essentially produce goods, which satisfy consumers' demands for food. In the long term an alternative source for satisfying this demand could come from the development of synthetics. The production oriented farmer would do little about this situation other than sit back and hope that the potential competition will not come about. The marketing oriented farmer, in contrast, would be prepared to respond to such developments. The obvious response would be for the farmer himself to investigate how far it would be possible for him to take some direct part in the 
development of synthetics.

Although this is unlikely to be feasible there are other, more realistic, alternatives. It is possible that the development of synthetics might strengthen the demand for "fresh food" unpolluted by artificial fertilizers, etc. the farmer who foresaw this and built up a reputation and a market for such produce would not suffer, but would actually benefit, from the development of synthetics.

The recent increase in the popularity of food grown using 'organic farming' methods is evidence of the potential for concentrating on a particular sector of the market (Barker, 1989).

\subsubsection{Marketing management}

Kotler (1972) a broader definition as "Marketing management is the analysis, planning, implementation and control of programs designed to bring about personal or mutual gain. First, it relies heavily on adaptation and coordination of product, price, promotion, and place for achieving effective response".

Marketing management is the art and science of choosing target markets, getting, keeping, and increasing customers through creating, delivering, and communicating superior customer value (Kotler, 2003.).

It is coordinated planning, implementation, and control of marketing efforts. (Evans and Berman, 1990).

The marketing manager performs all those functions, which are performed by all other managers. Major aspects of these functions are: (1) setting marketing objectives, including sales targets (2) planning the marketing mix comprising the product, pricing, promotion, and distribution, (3) organizing, (4) staffing, (5) coordinating, (6) directing and (7) controlling.

\subsubsection{Marketing performance}

Marketing performance is defined as the way in which markets and marketing contribute to various aspects of economic performance. Performance criteria could be divided into two categories, namely those related to economic efficiency and other performance objectives.

The former group includes technical efficiency, operational efficiency and exchange efficiency, while the latter group includes innovation, inter-sectional resource transfer, equity, employment, and co-ordination efficiency (Scarborough and Kydd, 1992).

Performance expectations are based on a company's strategic goals, the standards that met or exceeded by leading marketers. Standards may be established on the basis of the company's vision for the future, historical company data and forecasts for future performance, or by benchmarking against key success factors in the industry. A firm established performance criteria consistent with its mission and objectives. Typically marketing managers are concerned with overall performance in five key areas as they apply to design and implementation of the marketing mix: profitability, productivity, liquidity, and leverage (Anderson and Vaincze, 2000).

\subsubsection{Marketing channels}

Marketing channels are sets of interdependent organizations involved in the process of making a product or services available for use or consumption. Marketing channel decisions are among the most critical decisions facing management (Kotler, 2003). The sequence of intermediaries and markets through which goods pass from producer to consumer is known as marketing channel (Kohl and Uhl, 1985). The complex pattern of marketing channels and the part played by each in the total market movement can be shown best in flow charts (Abbott, 1958). The importance of the distribution function in marketing is apparent when one considers the magnitude of goods and services that are transported and sold at millions of locations though out the world. Mangy experts believe that the distribution decision is the most important marketing decision a company can make. The design of an organization's distribution system is a key factor in creating customer value and in differentiating one company's offering from that of another (Anderson and Vincze, 2000). As Anderson and Vincze (2000) noted, the field of distribution is made up to two distinct branches: channels of distribution and physical distribution. Channels of distribution consist of a network of intermediaries that mange a flow of goods and service from the producer to the final consumer. The success of this network depends on relationships among manufactures (producers), wholesalers, retailers, sales representatives, and others. As products move from one intermediary to the next, exchange takes place-exchange of physical goods, intangible services, and value added dimensions. Physical distribution activities include the actual movement of goods and services (i.e., logistics), with a focus on transporting and warehousing them.

A number of well tried and tested channels have been used throughout generations by farmers, and the most important of these will be considered from the point of view of their use for particular commodities, and their individual advantages and disadvantages (Barker, 1989). There are two particular marketing channels through which farmers dispose of their output. They are marketing channels used by farmers acting independently and in unison.

\subsubsection{Farmers choice of marketing channels}

All farmers must utilize marketing channels of whether they are production-oriented or market-oriented, if they produce goods, which are in excess of their domestic consumption. For some, this is simply a matter of routine, selling though the same outlets year in and year out. However, farmers are required to choose between various marketing channels in order to dispose of their produce. Possibilities certainly exist for the market-oriented 
farmer to improve his profit potential, if he is prepared to spend time deliberating over which marketing channel to use, and then makes his decision on the basis of sound economic motives (Barker, 1989).

\subsubsection{Channels used by farmers acting individually}

When a farmer operates as an individual in the market, his ability to influence that market is negligible. Despite this disadvantage, the bulk of agricultural produce is marketed by farmers acting independently through various outlets (Barker, 1989).

\subsubsection{Marketing channels used by farmers acting in unison}

One of marketing channels used by farmers acting in unison is cooperative. One of the main aims of cooperation is to reduce the inherent weaknesses of farmer who operates as an individual in the market, since the influence of the individual on the market is severely limited by the relative smallness of his scale of operations compared to the people with whom he is trading. This has long been held that if farmers act in the market, not as individuals, but cooperate in some way to market their produce in unison, and then there will be synergistic returns available because of the increased scale of operation. When farmers cooperate, there is a pooling of a variety of resources, including management and marketing competence and know how (Barker), 1989).

The rationale behind the legislation establishing farmers' rights to form cooperatives is that farmers generally market their crops to large, highly organized, commodity merchant firms or to large processing firms. Since these firms combine expertise and capital, farmers should be allowed to develop their own marketing firms in order to deal (complete) with them on equal footing (Douglass and Norvell, 1983).

\subsubsection{Legal Organization of Business}

From the standpoint of legal organization, there are three basic types of private business organizations in the free enterprise system: individually owned businesses; partnerships of two or more persons; and corporations. Corporations may be either profit-type (standard investor-oriented) or non-profit type (patron-oriented or Cooperatives). It may be just as well to classify the forms of business organizations as:

1. Individually owned businesses or sole proprietorships

2. Partnerships

3. Standard or regular corporations

4. Cooperatives

\subsubsection{Cooperatives}

\subsection{Concepts of cooperatives}

The international Cooperatives Alliance (ICA, 1995) defines cooperative, as "an autonomous association of personas, united voluntarily to meet their common economic and social needs through jointly-owned and democratically-controlled organization/enterprise". In its own definition, the international Labor Organization (ILO) also points out that members accept a fair share of the risks and benefits of their cooperative undertakings (ICA-UN, 1995). A cooperative has been defined by the Central Council for Agricultural and Horticultural Cooperation as an "association of producers/consumers who together can achieve some commercial objective more successfully than they can as individuals" (Barker, 1989).

A cooperative is a business voluntarily owned and controlled by its member patrons, and operated for them and by them on a nonprofit or cost basis. A cooperative enterprise belongs to the people who use its services, i.e., members control it, and its gains are distributed to the members in proportion to the use they make of its services.

It is organized and incorporated to engage in economic activities with certain ideas of democracy, social consciousness, and human relations included. A cooperative provides services and benefits for its members in proportion to the use they make of their organization rather than earning profits for the shareholders as investors. A cooperative is part of free enterprise, competitive, capitalistic system rather than a welfare agency or charitable and benevolent society. The primary goal of a cooperative is to meet members' needs in an economical, efficient manner, whereas the goal in the investor-oriented corporation, the partnership, and the sole proprietorship is to maximize profits for the owners of the business (Marvin A., 1980).

The basic principles of cooperative societies as a form of self-help and mutual help are the membership shall be open and not determined by religion, sex, race, political stand, or other considerations irrelevant to the objectives of the society, that the affairs of the society be controlled in a democratic manner on the basis of one man one vote, not in proportion to capital, that interest on capital be fixed, and the members benefit from the activity of the society in proportion to the business they do with it. In essence, membership is voluntary, based on mutual interest in removing disadvantage or achieving the desirable objective, and requiring a willingness and ability to conform the conditions agreed upon (Belshaw, 1959; cited in Zemen, 2005).

A true cooperative is defined as "a business voluntarily organized, operating at cost, which is owned, capitalized and controlled by a member patrons, sharing risks and benefits proportionally on their participation". Cooperative may render at least four valuable services at capitalistic system of which they are a part: (1) enhance private property, 2) preserve market competition, 3) retain profit motive and 4) maintain and strengthen the individual consumer and entrepreneur. The main purpose of the cooperatives is to make a profit for its patrons or users of the cooperative, not for its investors. The member of cooperative serves themselves. They are both the 
owners and users of the service. A contractual arrangement between the cooperative and the member patrons required that all margin above the cost of production be returned to the member patrons in proportion to their business with the cooperative (Roy, 1965).

\subsection{Agricultural cooperatives}

Being in the framework of the general cooperative concept, an agricultural cooperative represents an attempt by farmers, each of who has a different set of resources and perhaps goals, to integrate vertically in to the food and fiber system. The cooperative involves farmers, qua farmers, however; an elected board of directors, hired management, organized labor, government officials, bankers, and others may be involved in decision by cooperatives (Staath, 1965).

\subsection{Agricultural marketing cooperatives}

In agricultural marketing cooperative, farmers join together to market part, or all, of the produce of their holdings. The theoretical basis for such cooperation is related to three major factors.

1. Bargaining power: increasing farmers' bargaining strength, which is weak and disorganized in relation to buyers.

2. Marketing economies: reducing the cost of marketing by improving the efficiency of existing services, or achieving scale of economies in certain operations.

3. Market investment: providing an additional investment opportunity in marketing of a commodity or commodities covered by the cooperative is considered as an additional enterprise to those already carried out by the farmer (Barker, 1989).

\subsection{Cooperative movement in Ethiopia \\ 2.2.1 Imperial regime}

Modern cooperatives were introduced in Ethiopia soon after the Italian invasion of 1936. But, however, it was only in 1960s that cooperative was legally enacted (Federal cooperative Agency, 2005).

The Ethiopian Majestic Government attempted to organize the land-less people and the retired military into agricultural cooperatives through the Ministry of National Community Development in 1960. Accordingly the government issued also a farm workers Decree number 44/1961 to facilitate the organization of land-less people into cooperatives. However, it did not work well because the scheme met various problems that arose directly or indirectly from the then landlords who feared that the project/ scheme would eventually diminish the tenant work force on which they totally depend for cultivation. The plan was to organize about 20 cooperatives but it was accomplished only 2. As most of the land lords were at the same time, part of the existing government machinery, it was not so disrupt any program that seemed to work against their interests (Yeshital and Zehirul, 1997).

However, a modern cooperative in Ethiopia was started first in 1961. During this time the first cooperative legal action was made and it is known by Decree number 44/1961. the main reasons for this decree was the increase in the number of unemployment, the fast increase of migration from rural area to urban, the increase in number of students who drop out of their education, and finally the disarmament of the military without proper compensation and pension. Meanwhile, in order to incorporate the international principles and regulation of cooperatives, the above decree was replaced by proclamation number 241/1961.

According to Wolday (2003), cooperative movements in Ethiopia started to accelerate in the late 1960s with the launching of the comprehensive agricultural development projects such as the Chilalo Agricultural Unit (CADU). According to yeshitla and Zehirul (1997), the employees of Ethiopian Airlines organized the first savings and credit unions (cooperatives) in the country in 1964. In 1966, the government issued a special proclamation for this type of cooperatives, which became popular among the formal sector employees. All primary credit unions were associated with Ethiopian Thrift and credit cooperative societies Ltd (ENTACCS) as national apex body. ENTACCS became a member of the African Confederation of Credit Unions (ACCOSCA) in the same year. The number of savings with credit unions continued to increase even after the abolition of the national apex body in 1975 .

After the "Cooperative Societies Proclamation" of 1966, the modern cooperative began to emerge in Ethiopia. The third five-year plan (1968-1973) also placed great emphasis on the formation of cooperatives in the rural sector and multi-purpose agricultural cooperatives were considered to be among the best institutional forms for carrying out programs necessary for the development of peasant agriculture. The target of establishing new cooperatives was to create 300 new ones, of which 158 were formed. Out of 158,98 agricultural multipurpose cooperatives, 23 coffee growers cooperatives and the remaining were other types of cooperatives such as consumers, weavers etc.

During that time, relatively wealthy farmers who often employed land-less people as farm workers formed most agricultural coffee cooperatives. The main purpose of joining cooperatives at that time was to get loans for farm inputs, funds for processing and marketing of coffee. However, the coffee grower cooperatives were almost entirely engaged in marketing activities aimed at obtaining better prices for their members. But only a small portion of the marketed Ethiopian coffee was sold through cooperatives. Virtually no inputs were distributed to 
growers by these cooperatives.

Much cannot be said about these cooperatives, as they were practically at their infant stages by the time the Derg regime took over the leadership of the country. As it is well known the military government had destroyed all rural as well as urban institutions including the multi-purpose cooperatives that were replaced by new types of rural organizations in line with socialist doctrines.

\subsubsection{Derg regime}

\subsubsection{Peasant Associations}

Shortly after the revolution of 1974, Peasant Associations emerged as a result of proclamation (No. 71 of 1975) and proclamation number 138/78 issued by the military government on land reform and cooperative organization respectively. Peasant associations, the lowest form of administrative hierarchy were mainly formed to consolidate peasants' participation in political, economic and social activities of the nation. The peasant associations not only replaced the traditional rural administrative organs in regard to land distribution, land use, and local defense, but also, aimed at rural self-administration, cooperative organization, and villagization programmes. They were also engaged in assessing input needs and the distribution of inputs to the peasants (Yeshitla and Zehirul, 1997).

\subsubsection{Service cooperatives}

The proclamation on land reform and cooperative organization proclamation stipulated that service cooperatives were to be formed by 2 to 10 peasant associations. The objectives of the service cooperatives were mainly to provide the following services to the members.

1. Provide political education with a view to establish agricultural producers' cooperative societies,

2. Provide extension services,

3. Provide marketing services for the produce of members at fair prices,

4. Arrange loans for members at fair interest rates,

5. Provide storage and savings services,

6. Supply consumer goods to members according to needs, and

7. Supply improved agricultural implement and provide tractor services.

\subsubsection{Producers' cooperatives}

The Derg regime considered service cooperatives just as a first step of a massive "co-operatization" program, which ultimately aimed at transforming the rural economy into the socialist mode of production. Therefore, the individual farmers were encouraged to form producers' cooperatives with collective ownership of production.

The organization and stage-by-stage development of producers' cooperatives was elaborated in the 1979 directives of agricultural producers' cooperatives. There were three stages as per directives:

1. Malba - (Primary)

2. Wolba - (Advanced), and

3. Weland - (Union of Wolbas)

1. Malba: It required transferring private holdings of land to communal holding leaving $1 / 5^{\text {th }}$ of a hectare, for individual cultivation. Draught animals and farm implements were to remain private property and the cooperative would pay rent to owners.

2. Wolba: In the advanced producers' cooperatives, all land holdings becomes communal holding and all animals and implements are transferred to cooperatives. The farmers can individually cultivate up to 1/10th of a hectare. All members or a minimum of 30 members of peasant associations could form advanced cooperatives.

3. Weland: It was a union of advanced agricultural producers' cooperatives having an average land holding of 4000 hectares and membership of 500 peasants.

Generally, the peasant does not like the idea of producers' cooperatives. Peasants in fact were forced to setup such cooperatives. The dislike for these kinds of cooperatives could be witnessed immediately after the declaration of the economic reform program in 1990, which stipulated, "The organization of the cooperatives was not based on the absolute democratic decision of the members". The result was that some of the service cooperatives and almost all of the producers' cooperatives were bring to an end by their own members.

The steps taken by the cooperative organization clearly indicates that any form of organization without the full and direct participation of the beneficiaries will never be successful (Yeshitla and Zehirul, 1997). However, up to 1990 there were 10,524 different types of cooperatives with 4,529,259 members and total capital of Birr $465,467,428$ throughout the country. From these cooperatives, 80 percent were rural cooperatives (Zemen, 2005).

\subsubsection{Present regulation}

\subsubsection{Preliminary period}

During the change of Derg regime by the present government of 1991, the negative view towards cooperatives was manifested in the actions of the farmers looting and destroying of the properties and records of their cooperatives. According to Dessalegn (1994), more than 24 million Birr was misappropriated by those cooperatives, which the Ministry of Agriculture had audited. The audited cooperatives were certainly not more 
than $25 \%$.

\subsubsection{Present time activities}

The current free market economic policy believed on the importance of the cooperatives. Furthermore, the cooperatives are expected to perform a great role in the marketing of goods and services to satisfy the needs of producers and consumers.

The present government issued a proclamation on agricultural cooperatives societies named proclamation number 85/94 in 1994 (Yeshitla and Zehirul, 1997). This proclamation incorporates the international cooperative principles; however, its focus was only to solve the rural cooperatives problems. In addition there was no separate entity to support these cooperatives both at federal as well as regional level (Zemen, 2005).

At present, cooperatives are playing significant role in the rural Ethiopia economy specially, in the area of input supply, saving and credit, coffee and cereal marketing. The establishment of cooperative unions in coffee and cereal growing areas, as well as the startup of cooperatives Federation in areas of grain, coffee, dairy and saving \& credit activities is a great deal achievement to improve the agricultural marketing system in the country in general, and increasing the livelihood of the farmers and the general citizens in particular.

The present times economic policy and rural development strategy of the country, cooperatives are taken as pertinent institutions or tools to advance the livelihood of the general population. To realize this responsibility, the process of cooperative policy formulation becomes an important factor to organize and promote cooperatives as to participate in the economic (marketing) activities of the nation in the future.

\section{RESULTS AND DISCUSSION}

\subsection{Descriptive Analysis}

Descriptive analysis is used to elaborate and helps to understand the socio-economic and institutional characteristics of the sampled household and members and officials of the coffee marketing cooperatives organized in the study area.

\subsubsection{Household Characteristics}

\subsubsection{Age of Household}

The age of the sampled household heads, ranges from 19 to 82 years. The average age of the sampled heads is about 45.4 years. About $90.83 \%$ of the respondents were found in the most actively working age category (19 to 64 years).

Table 1 Distribution of sample farmers by age groups

\begin{tabular}{|l|l|l|}
\hline Age Category & $\mathbf{N}$ & \% \\
\hline $19-45$ & 39 & 65 \\
\hline $46-64$ & 15 & 25.83 \\
\hline Above 64 & 6 & 9.17 \\
\hline Total & $\mathbf{6 0}$ & $\mathbf{1 0 0}$ \\
\hline
\end{tabular}

\subsubsection{Agro-ecology and personal characteristics}

Out of the 60 sampled respondents, $88.33 \%$ were dwelling in woyina dega (semi-humid or midland) and $11.67 \%$ were in lowland area. With regard to sex characteristic, $97.50 \%$ of the sampled household were male headed and $2.50 \%$ was female headed. This indicates that nearly the entire cooperative member households were male headed. Even though female's participation in the cooperative is encouraged, females' involvement was very low, in the study area.

With respect to marital status, $97.50 \%, 1.70 \%$ and $0.80 \%$ of the respondents were married, single and divorced, respectively. Most of the sampled households in the study area follow protestant religion (79.17\%) and the rest of the respondents $9.17 \%, 6.67 \%, 4.17 \%$ and $0.83 \%$ follow Orthodox, Muslim, catholic and no religion, respectively, the culture and religion as be an important influence to the strategic development endeavor, the above information could be utilized for the extension of organized and efficient marketing activities for the area in question (Table 2). 
Table 2.Distribution of sample farmers by agro-ecology and personal characteristics

\begin{tabular}{|l|l|l|}
\hline Characteristics & $\mathbf{N}$ & $\mathbf{\%}$ \\
\hline Agro-ecology & & \\
\hline Midland & 53 & 88.33 \\
\hline Lowland & 7 & 11.67 \\
\hline Sex & & \\
\hline Male & 58 & 97.5 \\
\hline Female & 2 & 2.5 \\
\hline Religion & & \\
\hline Orthodox & 5 & 9.17 \\
\hline Muslim & 4 & 6.67 \\
\hline Protestant & 48 & 79.17 \\
\hline Catholic & 2 & 4.17 \\
\hline No religion & 1 & 0.83 \\
\hline Marital Status & & \\
\hline Married & 57 & 97.5 \\
\hline Single & 2 & 1.7 \\
\hline Divorced & 1 & 0.8 \\
\hline 3.1.3 Famiy side & \\
\hline
\end{tabular}

\subsubsection{Family size and educational status of farm households}

The average family size of the sample farmers was 4.77 persons, with maximum and minimum family size of 13 and 2 persons respectively which makes the area as densely populated. Out of the total family members (572) of the sampled household, the number and proportion of children who were less than 15 years, economically active $(15-64)$ years, and elderly (>64) years old were found to be, $242(42.31 \%), 326(56.99 \%)$ and $4(0.70 \%)$ respectively.

As it is observed on (Table 6), out of the sampled household, (13.33\%) were illiterate. The rest had attended elementary (55.83\%), junior secondary (20.84\%), and high school (10.00\%) education.

Table 3.characteristics of education status and family size of sample farmers

\begin{tabular}{|l|l|l|}
\hline Characteristics & N & \% \\
\hline Household family size & & \\
\hline Children $<15$ years & 121 & 42.31 \\
\hline 15-64 years & 163 & 56.99 \\
\hline$>64$ years & 2 & 0.70 \\
\hline Household educational status & & \\
\hline Illiterate & 8 & 13.33 \\
\hline Elementary (1-4) & 34 & 55.83 \\
\hline Junior (5-8) & 12 & 20.84 \\
\hline Secondary school (9-12) & 6 & 10 \\
\hline 3.1.4 Landholding
\end{tabular}

\subsubsection{Landholding, work experience and asset ownership of farm households}

As indicated in table 4 , in the study area, the average land holding was 0.79 ha per household. Based on sampled farm households, the proportion of farmers land holding, less than 0.5 ha, between 0.5 ha and 2 ha and greater than 2 ha were $29.17,65 \%$ and 5.83 respectively.

Out of sampled households, all were practicing farming activities, mainly garden coffee farming system earning an average annual income of nearly Birr 2942.65. Some of the farmers were practicing off and non-farm activities with the proportion of $32.5 \%$ and $11.67 \%$ and earned an average annual income of birr 670 and 272 respectively.

Table 4 Distribution of sampled households, by the land holding, work experience and asset ownership

\begin{tabular}{|l|l|l|}
\hline Characteristics & $\mathbf{N}$ & $\mathbf{\%}$ \\
\hline Landholding (ha) & & \\
\hline Less than 0.5 & 17 & 29.17 \\
\hline Between 0.5 and 2 & 39 & 65 \\
\hline Greater than 2 & 4 & 5.83 \\
\hline Farm experience & & \\
\hline Farming activities & 60 & 100 \\
\hline Off-farm experience & 20 & 32.5 \\
\hline Non-farm experience & 7 & 11.67 \\
\hline
\end{tabular}




\subsection{Major crops produced and farming system of households}

As presented in table 8, in the study area, coffee is the dominant crop produced and the basis of livelihood. Every farmer was cultivating in his garden followed by Enset. Empirically, the sampled farmers confirmed that together with the major crop Coffee $(0.59 \mathrm{ha})$, they were also producing other products like Enset (false-banana) $0.25 \mathrm{ha})$, Maize (0.11 ha), Fruits (0.06ha), Chat (0.017ha) and others (0.005ha).

About $85 \%$ of the farmers in the area were practiced intercropping haricot bean $(51.67 \%)$, enset $(25 \%)$, and peas $(23.33 \%)$ with coffee. The reason of intercropping was reported as for consumption purposes $(93.33 \%)$ and because it helped them to produce more coffee (6.17\%). Production of coffee in the study area was undergone using shade trees. Out of the consulted farmers $(84.17 \%)$ of them reported as they were using shade trees and the types of trees used were Enset (22.50\%), Wanza (2.50\%), and both of them (75\%).

Either to replace the old coffee tree or to expand coffee plantation, farmers are practicing planting of new coffee seedlings. In the study area, $75 \%$ of the sampled farmers were planted coffee seedlings and the sources of seedlings were from both farmers' own nursery $(76.67 \%)$, from market $(20.83 \%)$ and from woreda bureau of agriculture and rural development $(2.50 \%)$.

In solving production and marketing problems of the farmers, the government employed extension agents to serve around the farming area. Extension and education provide skilled human resources that are needed to enhance the technical capacity of farmers and other system actors, and otherwise stimulates innovation processes in agriculture like the research system, Ethiopia's agricultural extension and education systems has experienced a growth in funding since the early 1990s and several structural transformations (Berihanu, et al, 2005). However, in the survey area, the majority of sampled farmers (80.83\%) reported as they faced production problems. The most important production problem in the study area was land scarcity $(83.33 \%)$ followed by coffee berry disease, Coffee Berry Disease (CBD) (6.67\%) Most of the respondents (93'33\%) had been contacted extension workers in different time schedules. The majority of the farmers reported as they were contracted the extension agent weekly (71'67\%). The rest had a chance to contact extension agents only monthly (21.67\%), twice in a year $(5 . \%)$ and once in a year $(1.67 \%)$. The extension advices were geared to largely in improving coffee production and productivity such as coffee pruning, grafting and post harvest management.

\subsection{Grading practices}

Grading of coffee is one of the methods of increasing the price of it by sorting the product (coffee) in the different quality levels. High quality coffee sellers eventually are rewarded through price difference paid by purchasers than low quality coffee sellers.

Respondents in the study area were asked about the grading and grading systems of their coffee. About $80.83 \%$ of respondents were sorted/graded their coffee. They were utilized various indicators for grading of coffee such as; size, color, extent of damage, cleanness, maturity and uniformity, for both red and dried cherry. The farmers were also asked about the demand of coffee in the area comparing red and dried cherry, and they responded that red cherry was more demanded than the dried one. About $89.17 \%$ the respondents said red cherry has more demand than dried cherry $(2.50 \%)$ and some of the farmers $(8.33 \%)$ were reported as both form of coffee demanded equally. As to the packing material used to bring the coffee to the market was by sisal sack $(86.67 \%)$, plastic sack (11.67\%) and basket (1.67\%).

\subsection{Coffee marketing problems}

Marketing problems are factors that cause market inefficiencies. Market inefficiencies will lead to hosting unsatisfied customers, or members for the cooperatives, and high marketing costs. In this study, sampled farmers were asked about the presence and types of marketing problems. Out of the total respondents, 91.67\% of them reported they faced marketing problems. The types of marketing problems they faced were reported as from the most to the least problematic factor was observed as under. Coffee price fall $(87.50 \%)$, transportation (43.33\%), theft (38.33\%), price setting (27.97\%), market information (24.17\%), scaling/weighing (23.33\%), operational/management know-how $(17.50 \%)$, packing materials (1.67\%), storage (4.17), grading system $(1.67 \%)$ and double taxation $(1.67 \%)$ were subsequent marketing problems of the farmers in the study area. The result points out that, the dominant problems rest on the price fall and instability of coffee price followed by transportation that expressed, as it was unavailable and/or expensive. Theft and price setting problems was also the next prevailing problems that was expressed by the farmers as matured coffee cherries were collected by thieves during the night and price was decided without the knowledge of the producers respectively.

\subsection{Cooperatives management and members' participation}

The management of cooperative is composed of three separate and distinct groups: members, directors and managerial staff. If requires the active participation of all three categories to make the cooperative wellcoordinated. Members formulate policies by adopting the articles of cooperation's and bylaws, and through action taken at annual and other meetings. However, they delegate to the board of directors the responsibility of 
translating these policies into action. It is the duty of directors to safeguard the interest of members.

In this study, out of 60 sampled members $59 \%$ of them reported that they were satisfied in their cooperative services while the rest $41 \%$ reported that they were dissatisfied. In the same way, the sampled household revealed that, their satisfaction and dissatisfaction on the overall performance of their cooperative was in the proportion of $57.43 \%$ and $42.57 \%$ respectively.

The member's view of satisfaction or dissatisfaction was assessed based on both the participation in the formulation and implementation of their cooperative policies and regulations as well as their cooperatives performance of service delivery efficiency. The survey result on the participation shows that on the average, $60.83 \%, 44.17 \%$ and $38.33 \%$ of the sampled farmers had participated in the election of directors, planning activities and approving annual audit reports respectively. This result indicates that the participation of members in their cooperative decision making activities was considerably poor, especially in the planning of activities and approving the annual audit reports, which was below 50\% in both cases. Members in the study area, right after nominating the cooperatives managing body; were inclined to run away from their cooperatives and they were not controlling the physical and financial performances of their cooperatives. This situation opens the door for mismanagement of resources and lead to corruption. The negligence of members on the major cooperative decisions could result dissatisfaction to them and it will have a negative impact on the future development of cooperatives as a whole.

\subsection{Marketing Channels}

Generally, in the study area there were 33 private traders 13 cooperatives and four main marketing channels in which coffee was passing from producers to consumers. The first channel was passing coffee from producers via coffee marketing primary cooperatives to export through secondary cooperative (unions). In the second channel producers sold dried coffee to collectors who were selling to coffee marketing cooperatives to be exported directly through the Union. The third and the fourth channels participates rather larger number of marketing agents and in this way producers were selling their coffee either to collectors of dried cherry or wholesalers and collectors to wholesalers to export via exporter through auction market respectively. The coffee marketing channels could be sketched like.

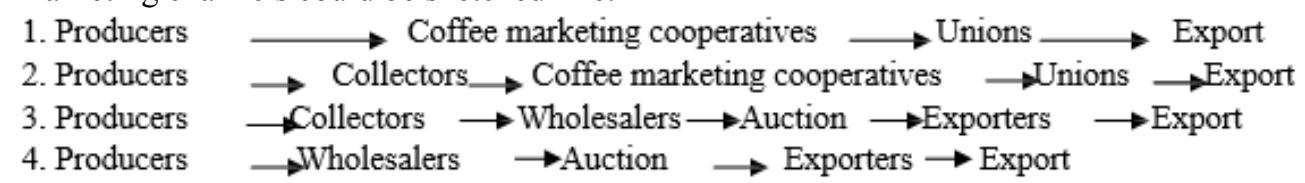

The informal channel was very much blamed by legal coffee marketing agents. It is the way through which coffee passes on to the unlicensed traders. Here farmers sell red cherry to informal traders to meet urgent cash needs usually when coffee marketing cooperatives face shortage of capital to purchase on cash terms. The same was mentioned by Demeke (2007) on his study on performance of coffee marketing cooperatives.

\subsection{Buying and selling strategy of the union}

The permanent customers for the Coffee marketing union were member farmers $(87.50 \%)$, other farmers \& local traders $(12.5 \%)$. From their supply side and the permanent buyers the Union $(97.50 \%)$. The purchasing activity was done in most of the time by themselves and their family which constituted about $(92.50 \%)$ followed by using agents $(7.50 \%)$. As the respondents' response, they were not trading all the year round and they were purchasing what was available in the market $(97.5 \%)$ and by expending credit to the farmers before harvest $(2.50 \%)$. The respondents were asked about the criteria they employ to check the quality of coffee during purchases, and $82.50 \%$ of them reported as they use color, shrinkage \& proportion of foreign matter and only $7.50 \%$ of them were checked the quality of the coffee bean using bean size. $55 \%$ of the respondents purchased coffee with price different from their competitors. As $50 \%$ of the officials reported in the study area, the price of coffee for the same day for all actors in the same market was not the same. This situation shows us that there was an information gap or communication barriers in the market that result in existence of market inefficiencies.

The discussion were conducted in four groups with 20 traders who are the nonmembers of the cooperatives in the study area and they were asked about marketing problems that they faced, and $40 \%$ of the traders agree on the problem of too much competition with unlicensed traders and cooperatives, where as $16 \%$ of the traders raised the overall shortage of coffee supply as their priority problem. The rest and the majority (44\%) of the traders agreed both problems were observed during the production year (2006/2007).

Sampled traders in the study area revealed that, they were selling their coffee to exporters $(76.5 \%)$ in central market. The rest $(23.5 \%)$ sold for different buyers in different time period. Tax was levied on traders by government or community officials at the market on the basis of either volume of the product, or per quintal, or birr/kg compared with their transaction was that it was very high (37\%), high (50\%) and fair (13\%).

With respect to ownership of processing machine, all cooperatives $(100 \%)$ and $75 \%$ of the traders engaged in coffee processing activities out of which $67 \%$ of the traders were owners and the rest $37 \%$ of the traders 
process coffee by rented machine. The greater number of sampled cooperatives reported that they grade their coffee in different grading systems to acquire a better price for their coffee. Some of the main grading systems were machine cleaning $(40.25 \%$, by liquoring (tasting) $(8.75 . \%)$ and smelling $(25.00 \%)$. Other grading systems include, color $(6.50 \%)$, size $(14.50 \%)$ and taste $(4.5 \%)$. With regard to packing material, cooperative use jute bag $(60.3 \%)$, polity line fiber $(39.7 \%)$ purchased from local market and the type and size of packing material was decided dominantly $(68.00 \%)$ by buyers or exporters. The major problem related to packing materials as reported by sampled officials were availability and quality followed by its price.

Transportation problem observed by the traders were long stay of trucks in Addis Ababa market (45\%), lack of feeder road/infrastructure $(20 \%)$ and both problems mentioned $(35 \%)$.

The most important infrastructural constraints that affected the traders business were lack of road $(35 \%$, lack of transportation (25\%), lack of processing machine in appropriate cite $(6 \%)$ and road, transport \& telephone $(34 \%)$. this result tells us that the main problem the traders faced was not only transportation but also other infrastructural frame works.

\section{Summary of findings conclusion and recommendation Summary of Findings}

The main service found between farmers and the union is the marketing. The permanent customers for Coffee marketing union were member farmers, other farmers \& local traders. From the supply side the farmers \& other traders and the permanent buyer is the Union. The purchasing activity was done in most of the time by themselves and their family followed by using agents. They were not trading all the year round and they were purchasing what was available in the market and by expending credit to the farmers before harvest. The member farmers are not satisfied with the work of their cooperative union, because, they did not fully participate in major activities and decision making process of the union. In addition, the marketing service of the union is not that much fast and transparent and these results in poor performance of the union. Members in the study area, right after nominating the cooperatives managing body; were inclined to run away from their cooperatives and they were not controlling the physical and financial performances of their cooperatives. This situation opens the door for mismanagement of resources and lead to corruption.

The dominant problems rest on the price fall and instability of coffee price followed by transportation that expressed, as it was unavailable and/or expensive. Theft and price setting problems was also the next prevailing problems that was expressed by the farmers as matured coffee cherries were collected by thieves during the night and price was decided without the knowledge of the producers respectively. The good opportunity to the union is the potential of the member farmers and other external farmers and the right \& capacity of export. There were 33 private traders 13 cooperatives and four main marketing channels in which coffee was passing from producers to consumers. The first channel was passing coffee from producers via coffee marketing primary cooperatives to export through secondary cooperative (unions). In the second channel producers sold dried coffee to collectors who were selling to coffee marketing cooperatives to be exported directly through the Union. The third and the fourth channels participates rather larger number of marketing agents and in this way producers were selling their coffee either to collectors of dried cherry or wholesalers and collectors to wholesalers to export via exporter through auction market respectively.

\subsection{Conclusion}

This study attempts to contribute to better understanding of the performance of coffee marketing system and member satisfactions of the various services provided by the coffee marketing union, using Bonga town as references.

The marketing channel of coffee in the study area was characterized by the participation of different marketing agent such as producers, collectors, primary coffee marketing cooperatives, wholesalers, unions, and exporters. In this study, four coffee marketing channels were identified and discussed in the result and discussion chapter. In all channels except one channel, in which wholesaler replaces the cooperatives coffee marketing cooperatives were purchasing coffee from producers with and without using collectors and sold their coffee to the union which directly exported to overseas markets.

The discussion were conducted in four groups with 20 traders who are the nonmembers of the cooperatives in the study area and they were asked about marketing problems that they faced, and $40 \%$ of the traders agree on the problem of too much competition with unlicensed traders and cooperatives, where as $16 \%$ of the traders raised the overall shortage of coffee supply as their priority problem. The rest and the majority $(44 \%)$ of the traders agreed both problems were observed during the production year.

Results showed that coffee marketing cooperative were inefficient in reference to computed efficiency ratios, income ratios and creditworthiness ratios. In reference to efficiency ratio, inventory turnover and operating ratio was used. Based on both inventory turnover and operating ratios, the coffee marking cooperatives in the study area, were inefficient as discussed before. This shows that the management of the cooperatives were 
either unable to manage their inventory or the expenses were not well controlled.

Basically farmers should be owners, user and controllers of their cooperatives. But, in the study area, it was observed that some farmers were using other marketing channels (traders) to sell their coffee. On the other hand, cooperatives in the study area use collectors to purchase coffee from farmers.

Generally, the results of the study shows the cooperatives under consideration were inefficient both on their business management and members handling that lead to the dissatisfaction of the members as customers though there is some sign of successes in the study area specially Bonga town peasant union.

\subsection{Recommendations}

Based on the data and results of this study the following points are recommended:

- More active participation and coordination of members, directors, and managerial staff and government bodies are required to make the cooperatives become more competent and efficient and need to perform regular and periodical performance evaluation in each year, must conduct general Assembly meeting as per the by-laws of the cooperatives in addition to annual auditing services to the cooperatives.

- $\quad$ Giving greater emphasizes for member satisfaction the members, the management bodies and the staff members of the cooperatives need to be given a capacity building training in business planning and development and marketing management, together with experience sharing within or outside the country with those cooperatives performing better. Further empirical investigation should also be required about the performance of the Bonga town coffee farmers' cooperative Union to draw sound recommendation that will help to maximize the owners satisfaction and better performance.

- $\quad$ Evaluating the performance of cooperative periodically to take appropriate measure and conduct annual auditing services as some of the cooperatives are not in a position to know their financial status evaluate the performance of cooperative periodically to take appropriate measure and conduct annual auditing services as some of the cooperatives are not in a position to know their financial status.

- Creating of conducive environment though formulation of sound cooperative policy that creates competitive cooperatives in satisfying their members.

\section{REFERENCES}

Abbott. J.C., 1958. Marketing Problems and Improvement Problems, FAO, Rome.

Admasu Shier. 1998. Performance evaluation of coffee marketing in Sidamo zone, M.Sc. thesis presented to Alemaya University of Agriculture, Alemaya.

Agriculture and Rural Development Department 2006.Gedeo Zone, Profile of Zonal BasicData, Dilla.

Agarwal R.D., 2004. Organization and Management. Tata McGraw-Hill publishing Company Limited. New Delhi.

Anderson.C.J. and Vincze. J.W., 2000. Strategic Marketing Management Houghton Miffilin Company, NewYork.

Asmare Hagos, 1989. The Impact of Farm size on the Efficiency of the Farmers Producers' Cooperatives: The Case of Harar Zuria Awraja, M.Sc. thesis presented to Alemaya University of Agriculture, Alemaya.

Burt, L., 1997. Organizing and Operating Agricultural Cooperatives. Oregon State University. U.S.A.

Coffee \& Tea and Trade \& Industry ministries, 2002. Agricultural Commodities Marketing Strategy study (final report paper). Addis Ababa.

CSA, 1999 and 2006. Central Statistical Authority, Yearbook. Addis Ababa

Federal Cooperative Commission, 2003/04. Legal framework of cooperatives, Training Manual.

Federal Negarit Gazeta, 1998. A proclamation to provide for the establishment of cooperative society. Proclamation No. 147/1998. Addis Ababa.

Federal Negarit Gazeta, 2002. A Proclamation to Establish Cooperatives: Proclamation No 274/2002, Addis Ababa.

Getenesh Sintayehu, 1988. Result Analysis and Result Comparison of farmers Producers' Cooperatives in the Highlands of hararghe, M.Sc. thesis presented to Alemaya University of Agriculture, Alemaya.

Green, W.H., 2002. Economic Analysis. Prentice Hall International, Inc. New York University.

Gujarati, D., 1999. Essentials of Econometrics. Second edition, United States Military Academy, West point

Kothari, C.R., (2004) Research Methodology Methods and Techniques. $2^{\text {nd }}$ ed, New Age International publisher, New Delhi.

Mamoria, Satish, and Suri, 2003. Marketing Management. Sarojini Naidu Marg, Allah bad. New Delhi-India. Marvin, A. S., 1998.Cooperatives, Principles and Practices, University of Wisconsin/ Extension/, Madison.

Mendoza, G.2002. A primer on Marketing Channels and Margins. Apart ado Aero 477, Popayan, Colombia.

MoA (Ministry of Agriculture), 1998. Basic data of the country Addis Ababa.

MoARD (Ministry of Agriculture and Rural Development), 2003. Annual Report 2002, Addis Ababa.

MoFED (Ministry of Finance and Economic Development), 2005. Annual Report 2005 Addis Ababa. 
NBE (National Bank of Ethiopia), 2007. Annual Report of 2005/2006, Addis Ababa.

Scarborough, Vanessa and Jonathan Kydd, 1992. Economic Analysis of Agricultural Markets, A manual. Marketing series 5, Chanthan: Natural Recourse Institute. UK.

SNNPRG, 2007. Agriculture and rural Development Bureau. Annual achievement Report of 2005/2006, Awassa.

SNNPRS, 2007. Finance and Economic Development Bureau. Abstracts of the region. Awassa.

Solomon Tilahun, 2002.Performance of Cattle Marketing in southern Ethiopia with Special Emphasis on Borena Zone.

Stephen McCarthy 2007.Linking smallholder producer groups to higher valve markets, a case study on "Ethiopia's coffee cooperatives" Washington

Teressa Adugna and Heidhues, F., 1998.Explaining the performance of Ethiopian Agriculture.

Wolday Amha and Eleni Gebre-Medhin, 2003. An analysis of the structure, Conduct, and Performance of the Ethiopian Grain Market, Addis Ababa. 